\title{
Late Quaternary changes in surface productivity and oxygen minimum zone (OMZ) in the northwestern Arabian Sea: Micropaleontologic and sedimentary record at $\mathrm{ODP}$ site $728 \mathrm{~A}$
}

\author{
AJAI K RAI* and S S DAS** \\ Department of Earth $\&$ Planetary Sciences, Nehru Science Centre, \\ University of Allahabad, Allahabad 211 002, India. \\ *e-mail:raikajai@gmail.com \\ **e-mail: siddharthasankardas.alld@gmail.com
}

Changes in the abundance of selected planktic foraminiferal species and some sedimentological parameters at ODP site 728A were examined to understand the fluctuations in the surface productivity and deep sea oxygenation in the NW Arabian Sea during last $\sim 540 \mathrm{kyr}$. The increased relative abundances of high fertility taxa, i.e., Globigerinita glutinata and Globigerina bulloides mainly during interglacial intervals indicate intense upwelling. Strong SW summer monsoon probably increased the upwelling in the western Arabian Sea during interglacial intervals and caused high surface productivities due to the lateral transport of eutrophic waters. Most of the glacial periods (i.e., MIS 2, 4, 6, 8 and 12) are characterized by higher relative abundances of Neogloboquadrina pachyderma and Neogloboquadrina dutertrei associated with Globigerinoides ruber. The more stratified condition and deep mixed layer due to increased NE winter monsoon are mainly responsible for the higher relative abundances of $N$. pachyderma during glacial periods. Some of the glacial intervals (i.e., MIS 6 and 8) are also characterized by pteropod spikes reflecting deepening of aragonite compensation depth (ACD) and relatively less intense oxygen minimum zone (OMZ) in this region due to deep sea mixing and thermocline ventilation, and relatively less intense surface productivity during winter monsoon. The interglacial periods are largely devoid of pteropod shells indicating more aragonite dissolution due to increased intensity of OMZ in the northwestern Arabian Sea.

In general, the interglacial periods are characterized by low sediment accumulation rates than the glacial intervals. On an average, the total biogenic carbonate percentages were higher during interglacial and during periods of higher surface productivity. Most terrigenous material was trapped on shelf during intervals of high sea level stands of interglacial, whereas more erosion of shelf increased the sedimentation rates during glacial periods. In addition, the fragmentation record may be the result of changes in intensity and vertical distribution of the OMZ with time. During glacial intervals, the lower boundary of the OMZ probably was in a shallower position than during interglacial periods, when dissolution increased as a result of higher organic production. The higher rates of sinking organic matter result into a stronger OMZ as oxygen is used to disintegrate the organic matter. This process lowers the $\mathrm{p}^{\mathrm{H}}$ of water which results into increased dissolution of calcium carbonate.

Keywords. Arabian Sea; Quaternary; productivity; oxygen minimum zone; planktic foraminifera; pteropod. 


\section{Introduction}

Strong variations in wind direction and intensity (Hastenrath 1989) result into changes in precipitation and aridity on the continents and influence the hydrography and trophic conditions of the adjacent oceans. The western Arabian Sea is characterized by large seasonal variations in current direction, upwelling intensity and mixed layer characteristics such as temperature, nutrient content and productivity (Wyrtki 1971, 1973). These seasonal changes are the oceanic response induced by the large scale monsoonal winds. The monsoon, driven by the strong atmospheric pressure gradient between land and ocean, causes a biannual reversal of the current patterns due to changing direction of monsoon wind. The summer monsoon is driven by differential (land-sea) sensible heating and tropospheric latent heating (Clemens et al 1991) which results in a distinct atmospheric circulation system with seasonally changing wind directions. Monsoonal winds drag sea surface waters of the northwest Arabian Sea influencing the surface circulation. The prevailing clockwise surface circulation during the SW monsoon causes coastal upwelling off Oman as well as open-ocean upwelling associated with the low level Findlater Jet, a northeast-trending stratospheric wind that crosses the Arabian Sea about $400 \mathrm{~km}$ off the coast of Arabian peninsula (Findlater 1974; Anderson and Prell 1991, 1993; Brock et al 1992; Lee et al 2000). This seasonal upwelling brings deep nutrient-rich, oxygen-poor and cold waters to the surface and increases the productivity in the euphotic zone (Krey and Bauered 1976; Nair et al 1989). Surface productivity has its annual maximum during the summer monsoon (Nair et al 1989; Haake et al 1993). Recently, Naidu and Malmgren (2005) suggested that the SST difference between summer and winter seasons are directly related to the upwelling intensity in the western Arabian Sea.

Several micropaleontological, sedimentological and geochemical studies reveal that changes in northern hemisphere summer insolation are the primary factors in determining the timing and intensity of monsoon winds (Clemens et al 1991; Reichart et al 1998; Schulz et al 1998). Many paleoceanographic studies have shown that the increased paleoproductivity can be related to the insolation maxima leading to enhanced SW summer monsoon. Intense summer monsoon occurred especially during interglacials forcing strong winds and an enhanced upwelling off the coasts of Somalia and Oman (Sirocko et al 1991). A relatively weak surface current flows in anticlockwise direction during the NE winter monsoon (Qasim 1982) which causes sea surface cooling

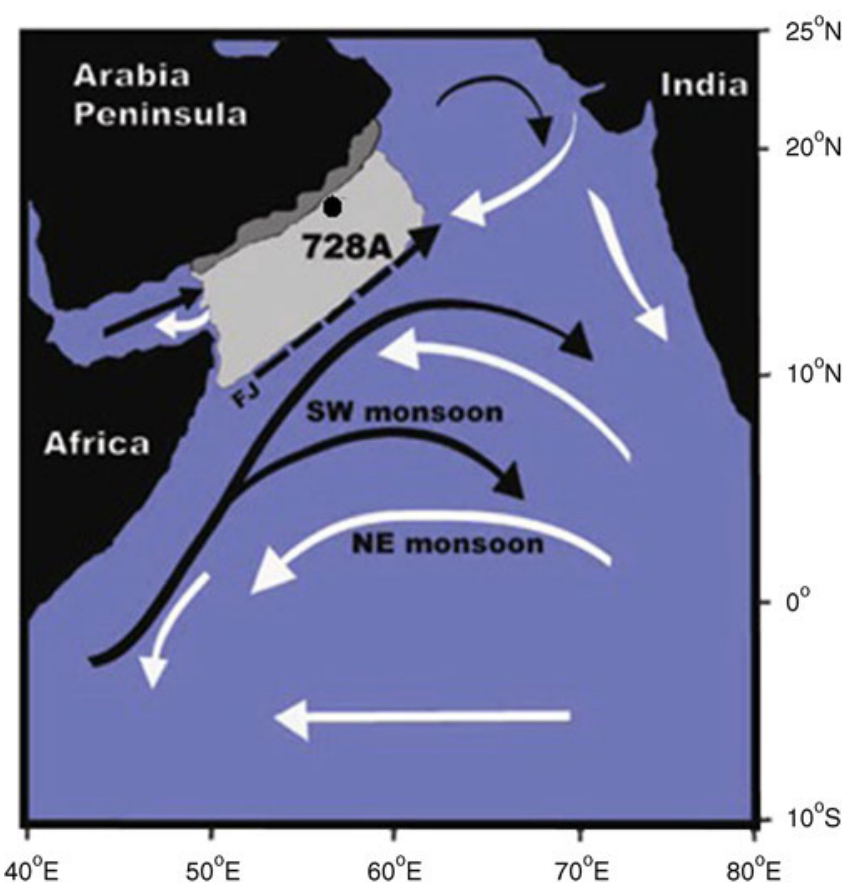

Figure 1. Surface hydrography in the Arabian Sea and location of ODP site 728A (solid circle; after Rai et al 2008). A strong clockwise surface ocean circulation (black arrows) develops during the SW summer monsoon, which follows the direction of the Findlater Jet (FJ, arrow with broken line). Coastal upwelling area is indicated by dark grey; and the open ocean upwelling area by light grey. Anticlockwise NE winter monsoonal circulation is indicated by white arrows.

and convective overturning (Bartolacci and Luther 1999). The convection processes lead to the injection of nutrient-rich water into the surface waters (Banse 1994) and this mechanism is supposed to be a dominant control on winter productivity (Madhupratap et al 1996) which is smaller than that in summer. Thus, both summer monsoonal upwelling and winter monsoonal convective overturn cause significant increase in surface productivity and zooplankton productivity in the Indian Ocean (Nair et al 1989; Conan and Brummer 2000).

Planktic foraminifera are sensitive to the oceanographic conditions in response to the monsoonal variations in the Arabian Sea (Cullen and Prell 1984; Brock et al 1992; Naidu and Malmgren 1995, 1996; Gupta et al 2003, 2005; Ivanova et al 2003; Schiebel et al 2004). Thus, the faunal compositions of planktic foraminifera are widely used to reconstruct the monsoonal variability. Site $728 \mathrm{~A}$ is located in the northwestern Arabian Sea on the continental margin off Oman (lat. $17^{\circ} 40.49^{\prime} \mathrm{N}$; long. $57^{\circ} 49.55^{\prime} \mathrm{E}$ ) in a water depth of $1428 \mathrm{~m}$ (figure 1). The location of ODP site 728A is suitable to understand complicated pattern of past upwelling and surface productivity conditions in 


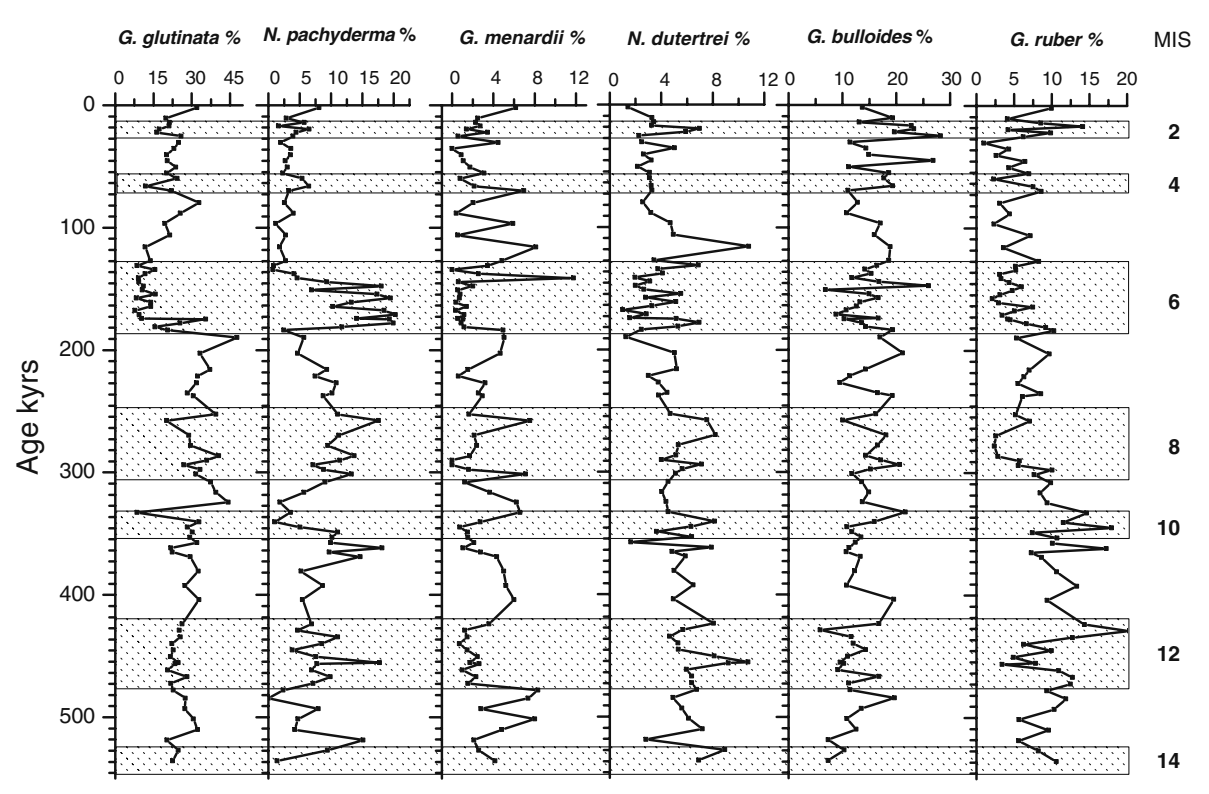

Figure 2. Time series plots of relative abundance of Globigerina bulloides, Globigerinita glutinata, Neogloboquadrina pachyderma, Neogloboquadrina dutertrei, Globigerinoides ruber and Globorotalia menardii at ODP site 728A (even numbered horizontal bars with dots represent glacial stages).

response to the variations in the northern Indian Ocean monsoon system.

\section{Material and methods}

The upper section of about $22.0 \mathrm{~m}$ thick was sampled at $25 \mathrm{~cm}$ intervals with a time resolution of approximately 6 kyr. Each core sample was treated with $10 \%$ calgon solution for about 20 hours, wet sieved by Tyler sieves through $125 \mu \mathrm{m}$ and then oven dried at $50^{\circ} \mathrm{C}$. After drying, samples of $>125 \mu \mathrm{m}$ fraction were weighed and examined under stereozoom microscope to pick the planktic foraminiferal and pteropod shells. Each sample over $125 \mu \mathrm{m}$ size fraction was splitted with a microsplitter into a suitable aliquot to contain about 300 planktic foraminiferal specimens. The percentage data of most abundant species were plotted against age in ka. The total number of pteropod shells per gram sediment was calculated. The average sediment accumulation rates and percentage fragmentation record of foraminiferal tests were taken from Steens et al (1991). The biogenic carbonate content of the bulk sediment samples determined by treating measured amount of oven-dried sediment samples with glacial acetic acid. The excess acid was removed by washing with distilled water. The organic matter content in the samples analyzed by treating the acid treated residue with $30 \%$ hydrogen peroxide. The remainder was thoroughly washed with water and dried to get terrigenous matter content. Age of each sample was calculated in ka following the time-depth relationship provided by Steens et al (1991).

\section{Results}

\subsection{Relative abundance of planktic foraminifera}

At ODP site 728A Globigerinita glutinata, Globigerina bulloides, Neogloboquadrina pachyderma, Globigerinoides ruber, N. dutertrei and Globorotalia menardii are the abundant planktic foraminiferal species. In general, G. glutinata and G. bulloides are the most dominant faunal elements constituting about $50 \%$ of the total assemblage. The abundance of G. glutinata remained relatively low during last $\sim 175$ kyr whereas, this species was more abundant prior to $\sim 175$ ka (figure 2 ). However, this species showed relatively higher relative abundance during most of the isotopic interglacial stages. The relative abundance of $G$. bulloides varies between $\sim 5$ and $28 \%$. We could not mark much definite trend in the relative abundance of this species with respect to the interglacial and glacial isotopic stages. However, this species increased significantly during glacial/interglacial transitions (figure 2). The relative abundance of $N$. pachyderma showed almost opposite trend to that of $G$. glutinata abundance mainly during glacial intervals. This species increased its abundance mostly during glacial stages such as MIS 4, 6, 8 and 12 with maximum abundance during MIS 6 (figure 2). 


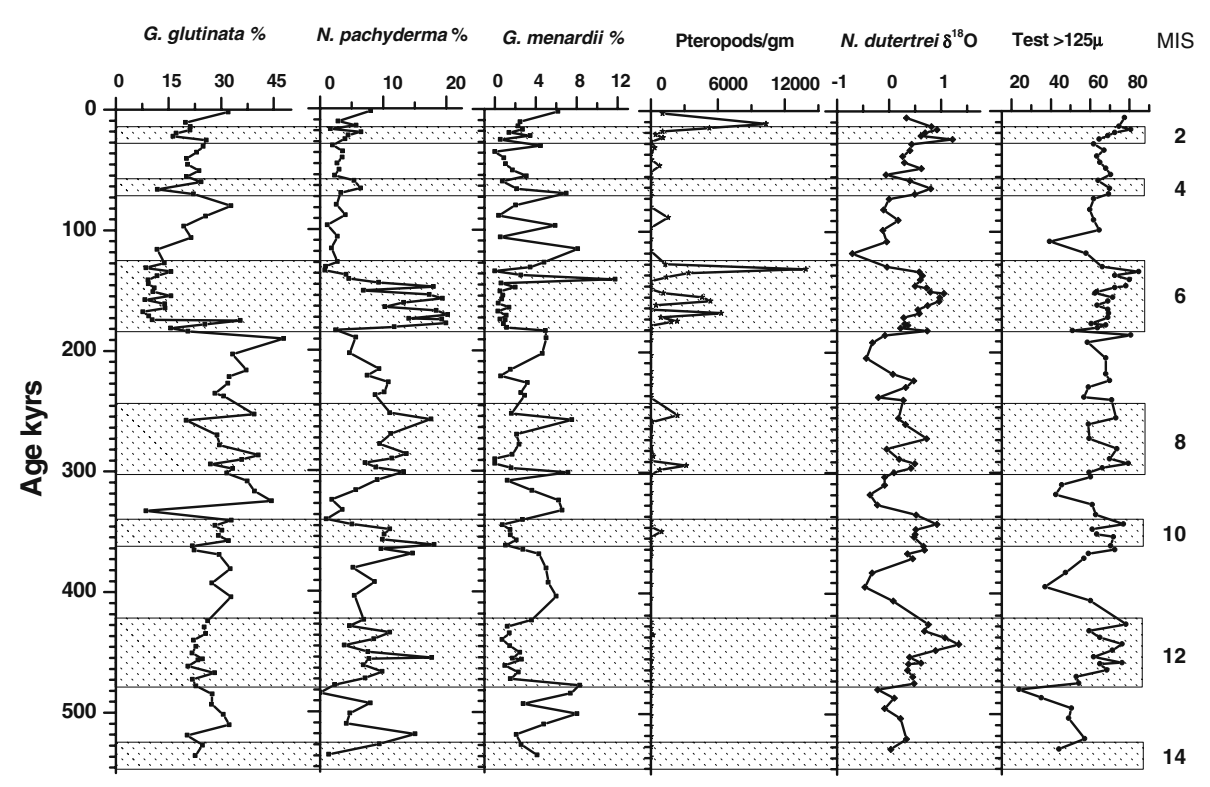

Figure 3. Time series plots of relative abundances of G. glutinata, N. pachyderma and G. menardii; number of pteropods/ gm; planktic foraminiferal $\delta^{18} \mathrm{O}$ values and foraminiferal fragmentation (Steens et al 1991) at ODP site 728A (even numbered horizontal bars with dots represent glacial stages).

Neogloboquadrina dutertrei also showed its relatively higher abundances during glacial MIS 2, 8 , 10 and 12 (figure 2). Globigerinoides ruber occurred with relatively more abundance in sediments older than $\sim 300$ kyr (figure 2). In general, the relative abundance of $G$. menardii remained higher during most of the interglacial periods (figure 3 ).

\subsection{Fragmentation, pteropod accumulation and Globorotalia menardii \%}

Fragmentation of foraminiferal tests was most pronounced during interglacial intervals which also had the higher relative abundances of the resistant species G. menardii mainly during MIS 1, 5, 9, 11 and 13 (figure 3). Aragonite preservation is also estimated by the total number of pteropod shells per gram which remains high during some younger glacial intervals, i.e., MIS 6 and 8 whereas older glacial intervals (i.e., 10, 12 and 14) and interglacial intervals are almost devoid of pteropod shell. During MIS 6, pteropods showed few prominent peaks of abundance which also correspond with the maximum relative abundances of polar-subpolar planktic foraminifer, N. pachyderma.

\subsection{Sediment accumulation rates, biogenic carbonate and terrigenous matter input}

Characteristic fluctuations in the sediment accumulation rates were observed during last $\sim 540 \mathrm{kyr}$ at site $728 \mathrm{~A}$. In general, interglacial intervals are marked with lower sediment accumulation as com-

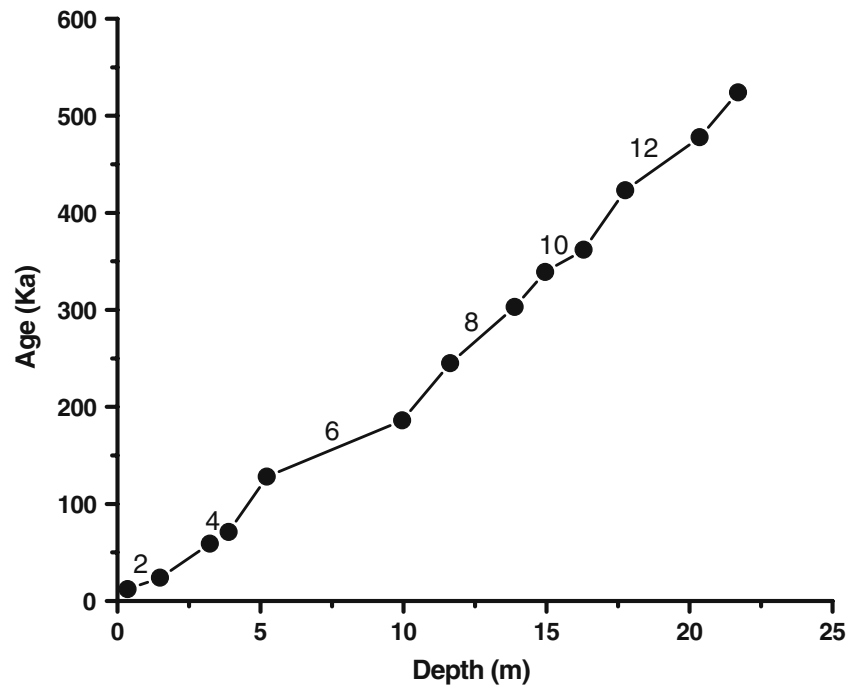

Figure 4. Sediment accumulation rates (even numbers on the curve indicate intervals of glacial stages).

pared to the glacial periods (figure 4). The higher percentages of terrigenous matter during glacial interval than interglacial (figure 5) are explained by the changing sea levels and eolian deposits. The terrigenous matter content showed antithetic relationship with the biogenic carbonate. The biogenic carbonate content at this site is characterized by higher percentages during most of the interglacial stages for the last $540 \mathrm{kyr}$. The organic matter content showed almost identical variation pattern to that of biogenic carbonate content (figure 5). 


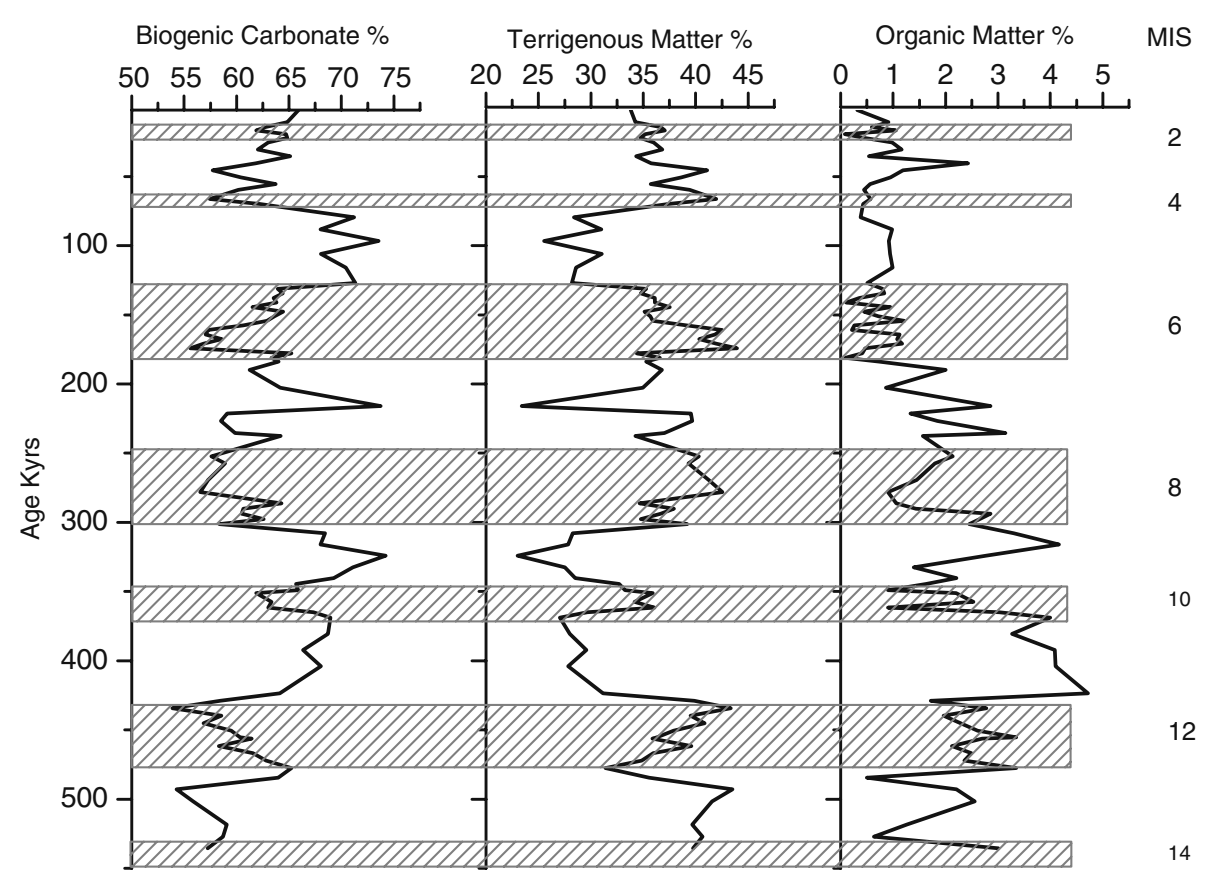

Figure 5. Time series plots of biogenic carbonate (\%), terrigenous matter (\%) and organic matter (\%) at ODP site 728A (even numbered horizontal shaded bars represent glacial stages).

\section{Discussion}

\subsection{Monsoonal upwelling and surface productivity}

The understanding of modern foraminiferal ecology is necessary for the paleoceanographic and paleoclimatic reconstruction employing the fossil record. The common planktic foraminiferal species recorded at ODP site $728 \mathrm{~A}$ are also reported from the upwelling areas of the Indian Ocean (Conan and Brummer 2000; Ivanova et al 2003). Globigerinoides bulloides thrives in subpolar regions and tropical upwelling areas and is widely used as a productivity indicator in monsoon-led upwelling regions like the Oman margin (Curry et al 1992; Naidu and Malmgren 1996; Overpeck et al 1996; Gupta et al 2003, 2008). Conan and Brummer (2000) reported that G. glutinata and G. bulloides are typical SW monsoonal upwelling species abundant in the upwelling areas off Somalia. Globigerinita glutinata is marked with higher abundances in the areas of open-ocean upwelling whereas $G$. bulloides is dominant in the regions of coastal upwelling (Anderson and Prell 1993; Ishikawa and Oda 2007). The abundant occurrences of both the species (mainly G. glutinata) at site $728 \mathrm{~A}$ during most of the interglacial intervals suggest intense upwelling. Enhanced interglacial SW summer monsoon probably increased the upwelling in the western Arabian Sea (Sirocko et al 1991; Emeis et al 1995) and caused high surface productivities in the entire Arabian Sea due to the lateral transport of eutrophic waters (Rogalla and Andruleit 2005). The scenario of interglacial interval was possibly closely similar to the present day conditions with a strong seasonality, high and low interannual productivity phases, and a distinct variation in surface water stratification. Ishikawa and Oda (2007) also suggested that the increased productivity due to intensified SW monsoonal upwelling was responsible for peaks in total planktic foraminiferal tests along with higher abundances of $G$. glutinata and G. bulloides in the western Arabian Sea during interglacial intervals. These events of high surface productivity were correlated with maximum insolation in July at $45^{\circ} \mathrm{N}$ (Berger 1978). Anderson and Prell (1993) suggested that intense SW summer monsoon occurred during interglacial times when the perihelion was aligned with the summer solstice, an orbital constellation that causes increased summer insolation in the Northern Hemisphere.

Most of the glacial periods (i.e., MIS 2, 4, 6, 8 and 12) are characterized by higher relative abundances of $N$. pachyderma and $N$. dutertrei associated with $G$. ruber (figure 2). Neogloboquadrina pachyderma, a common species in subpolar and polar ocean sediments, is commonly used to reconstruct paleoenvironmental conditions in cold oceans (Bé and Hutson 1977; Hemleben et al 1989). Kuroyanagi and Kawahata (2004) observed the dominance of this species below the pycnocline ( 20-40 m water depth) and at $<12^{\circ} \mathrm{C}$ temperature. 
Sedimentary data suggest that the distribution of $N$. pachyderma is influenced by stratification and deep chlorophyll maxima (DCM) (Hilbrecht 1997; Schiebel et al 2001). The NE winter monsoon is also characterized by enhanced surface productivity due to transportation of nutrients by deep wind-driven mixing and winter cooling (Veldhuis et al 1997). Thus, the more stratified conditions and deep mixed layer due to increased NE winter monsoon are mainly responsible for the higher relative abundances of $N$. pachyderma during glacial periods. Ishikawa and Oda (2007) also recorded higher surface productivity during glacial intervals in the northwestern Arabian Sea.

During glacial periods weaker pressure gradients between land and sea probably resulted into less upwelling in relatively weaker SW summer monsoons (Prell 1984). However, NE winter monsoons of glacial intervals were possibly stronger than during the interglacials due to higher pressure gradients. During glacial intervals the intense NE winter monsoon intensified the convective overturn which moderately increased the overall surface productivity (Rostek et al 1997; den Dulk et al 1998; Reichart et al 1998; Ivanova et al 2003). Benthic foraminiferal assemblages in the Gulf of Aden, an area strongly influenced by NE monsoon, also reflected enhanced surface productivity during glacial intervals (Almogi-Labin et al 2000). Thus, the variations in the distribution of planktic foraminiferal assemblage with respect to the glacial and interglacial periods reflected that the northwestern Arabian Sea was alternatively influenced by enhanced SW summer monsoon during interglacials and higher NE winter monsoon during glacial intervals. Recently, Gupta et al (2010) for the first time reported the evidence of midBrunhes ( 300-250 kyr) climatic event from the equatorial Indian Ocean and established a relation between Indian Ocean Dipole (IOD) dynamics and climate of the Indian Ocean. They suggested that weakening of Indian Ocean equatorial westerlies (IEW) and strengthening of IOD during 300250 kyr BP coincides with a shift towards dry conditions in Australasia, wet conditions in equatorial East Africa and a stronger Indian summer monsoon. We could also record the increase in $G$. bulloides and decline in $G$. ruber population during mid-Brunhes time $(\sim 300-250 \mathrm{kyr})$ reflecting stronger Indian summer monsoon possibly due to strengthened Indian Ocean Dipole (IOD).

During most of the transitional intervals from glacial to interglacial (e.g., MIS 2/1, 6/5, 8/7, 10/9 and $12 / 11$ ) the planktic foraminiferal species such as $N$. pachyderma, N. dutertrei and G. ruber were replaced by the dominance of G. glutinata and G. bulloides (figure 2). This change in the assem- blage of planktic foraminifera from dominance of NE monsoonal fauna to upwelling species suggests changing monsoonal condition during transitions from glacial to interglacial intervals. These transitional periods correspond well with the sudden increase in the sea surface temperature as indicated by decreased planktic foraminiferal $\delta^{18} \mathrm{O}$ values (figure 4). Abrupt increase in temperature causes a rapid melting of the inland glaciers, an extreme intensification of the summer monsoon and a weakening of the winter monsoon (Rogalla and Andruleit 2005). Thus, the changing foraminiferal assemblages suggested that the glacial/ interglacial transitional intervals are characterized by the reduced NE winter monsoon and accelerated SW summer monsoonal conditions which result into intense upwelling and surface productivity.

\subsection{Carbonate dissolution and $O M Z$ fluctuations}

Although ODP site 728A (water depth $1428 \mathrm{~m}$ ) is located well above the present day lysocline, dissolution of $\mathrm{CaCO}_{3}$ may occur even when the overlying water is supersaturated with respect to calcite. Release of $\mathrm{CO}_{2}$ during oxic decomposition of organic matter below the sediment-water interface can result in supralysoclinal $\mathrm{CaCO}_{3}$ dissolution (Morse and Meckenzie 1990). The biogenic carbonate content at this site varies between 50 and 70 (wt\%), and shows major peaks during interglacial stages for the last $540 \mathrm{kyr}$. The deposition of calcium carbonate on the sea floor is dominantly controlled by biological productivity in surface water, rate of dissolution through the water column as well as on the sea floor, and dilution by terrigenous matter. A negative correlation between biogenic carbonate and terrigenous matter may be due to the fact that the biogenic carbonate was diluted by the terrigenous matter supply. Closely similar relationships are also observed in the western, northwestern and southeastern Arabian Sea (Murray and Prell 1992; Clemens and Prell 1990; Pattan et al 2003; Das et al 2008). The organic matter content is also characterized by higher percentages during most of the interglacial intervals.

Since aragonite is more soluble than calcite, pteropod shells (made up of aragonite) dissolve rapidly when sinking through the $\mathrm{CO}_{2}$-rich water of OMZ. The regional aragonite compensation depth (ACD), therefore, lies nearly at the middle of the OMZ at about $500 \mathrm{~m}$ (Berger 1977) preventing good pteropod preservation at site $728 \mathrm{~A}$. Preservation of pteropod shells at this site thus, requires a substantial lowering of the ACD. It is therefore suggested that variations in the number of 
pteropod shells at site $728 \mathrm{~A}$ should be attributed to the changes in the $\mathrm{CO}_{2}$ content of the OMZ. It is significant that the higher pteropod preservation values are associated with relatively less intense surface productivity during glacial intervals (Rai et al 2008). This suggests that glacial periods of relatively less intense surface productivity are characterized by a substantially deeper ACD, and thus by a weakened OMZ. Reichart et al (1997) have reported that high pteropod preservation index values are associated with low values of $\mathrm{C}_{\text {org }}$ during glacial intervals due to low surface productivity. Thus, intervals of distinct peaks of pteropod abundance represent substantial deepening of the ACD and weakened OMZ in the NW Arabian Sea, possibly due to low surface productivity combined with the intense rates of thermocline ventilation. However, poor or no pteropod preservation during interglacials suggest a more strengthened OMZ and a shallow ACD during periods of higher surface productivity. This inference is also supported by the overall higher foraminiferal fragmentation during most of the interglacial intervals (figure 3 ). Recently, based on foraminiferal and organic carbon data, Gupta et al (2008) suggested a relatively well oxygenated OMZ during early Holocene where the influence of intense monsoon related production was reduced due to incursion of Circumpolar Deep Water (CDW).

Significant changes in sediment accumulation rates were observed for the past $\sim 540 \mathrm{kyr}$, with relatively low accumulation rates during the interglacial periods compared to the glacial intervals. Due to low sea-level stands during glacial periods terrigenous materials were eroded away from the shelf which increased the sediment acumulation rates. However, during higher sea level stands of the interglacial terrigenous materials are trapped on the shelf causing reduced sedimentation rates. Also more aridity and less vegetation cover during glacial intervals in the dustsource areas possibly resulted into higher influx of eolian particles (Steens et al 1991). The proximal position of the ODP site $728 \mathrm{~A}$ on the Oman margin also provides the possibility to study the influence of OMZ at its lower extreme. Presently, the lower limit of this zone extends up to a water depth of $1500 \mathrm{~m}$ (Wyrtki 1971). Since this site is located at a water depth of about $1400 \mathrm{~m}$, small fluctuations in the OMZ may strongly influence the depositional environment. The higher fragmentation and increased abundance of dissolution resistant species, G. menardii during interglacial intervals suggest strong dissolution. Also the changes in intensity and vertical distribution of OMZ with time influence the fragmentation record. In the OMZ, dissolution processes may affect the foraminiferal tests caused by undersaturation of calcium carbonate (Steens et al 1991). The lower boundary of OMZ became shallower during interglacial intervals when dissolution increased as a result of higher influx of organic matter. The increased supply of organic matter in the water column enhanced the intensity of $\mathrm{OMZ}$ as more oxygen is utilized to disintegrate the organic matter. Higher surface productivity during interglacial periods must have occurred as a response to stronger southwestern monsoon winds. The increase of sinking organic matter leads to a stronger OMZ as oxygen is used to disintergrate the organic matter. This process reduces the $\mathrm{p}^{\mathrm{H}}$ of the water resulting an increased dissolution of calcium carbonate. The connection between low surface productivity and a weak OMZ indicates that variations in the intensity of OMZ are controlled by mid-water oxygen consumption rates, although changes in mid-water oxygen advection cannot be completely disregarded. Schmiedl and Leuschner (2005) and Schmiedl and Mackensen (2006) also suggested that the vertical extent and intensity of the lower part of the OMZ were not only influenced by changes in monsoonal upwelling and associated organic matter flux but also by changes in the deep sea ventilation.

\section{Conclusions}

The distinct planktic foraminiferal assemblages at ODP site 728A during glacial and interglacial intervals reflect changes in the surface productivity and oxygen minimum zone during past $\sim 540 \mathrm{kyr}$. The strong SW summer monsoon causing intense upwelling in this region was mainly responsible for more pronounced surface productivity during interglacial periods. During glacial intervals weaker SW summer monsoons lower the pressure gradients between land and sea resulting into less upwelling. Whereas, strong NE winter monsoon of glacial period was responsible for more effective surface water convection and surface productivity. The changing planktic foraminiferal assemblages during transitional intervals from glacial to interglacial showed extreme intensification of SW summer monsoon and reduced NE winter monsoon resulting into intense upwelling and surface productivity. The increased abundance of pteropods during some glacial intervals (i.e., MIS 6 and 8) reflected significant lowering of the ACD along with less intense OMZ possibly in response to relatively low surface productivity and/or enhanced thermocline ventilation. Strong dissolution during interglacial periods was responsible for the higher abundances of dissolution resistant species, G. menardii and increased 
fragmentation. The higher influx of organic matter in the water column during interglacial intervals enhanced the intensity and vertical distribution of OMZ which was responsible for more dissolution. Thus, the microfaunal and sedimentologic data in the present study suggested that the changing monsoonal pattern during glacial and interglacial intervals influenced the surface productivity and OMZ in the NW Arabian Sea.

\section{Acknowledgements}

Ocean Drilling Program (ODP) is thankfully acknowledged for providing core samples for present investigation. We thankfully acknowledge the technical assistance provided by $\mathrm{S}$ Shukla and $\mathrm{P}$ Pandey. Authors are very much thankful to Prof. A D Singh for his valuable comments and suggestions on planktic foraminiferal taxonomy. We are also thankful to two anonymous reviewers for their valuable comments.

\section{References}

Almogi-Labin A, Schmiedl G, Hemleben C, Siman-Tov R, Segl M and Meischner D 2000 The influence of the NE winter monsoon on productivity changes in the Gulf of Aden, NW Arabian Sea, during the last 530 ka as recorded by foraminifera; Mar. Micropaleontol. 40 295-319.

Anderson D M and Prell W L 1991 Coastal upwelling gradient during the late Pleistocene; In: Proceedings of the Ocean Drilling Program (eds) Prell W L and Niitsuma N et al, Scientific Results 117 265-276.

Anderson D M and Prell W L 1993 A 300 kyr record of upwelling off Oman during the late Quaternary: Evidence of the Asian SW monsoon. Paleoceanography $\mathbf{8}$ 193-208.

Banse K 1994 On the coupling of hydrography, phytoplankton, zooplankton, and settling organic particles offshore in the Arabian Sea; In: Biogeochemistry of the Arabian Sea (ed.) Lal D, Proc. Indian Acad. Sci. (Earth Planet. Sci.) 103(2) 125-161.

Bartolacci D M and Luther M E 1999 Patterns of covariability between physical and biological parameters in the Arabian Sea; Deep-Sea Res. II 46 1933-1964.

Bé A W H and Hutson W H 1977 Ecology of planktonic foraminifera and biogeographic patterns of life and fossil assemblages in the Indian Ocean; Micropaleontology 23 369-414.

Berger W H 1977 Deep-sea carbonate: Pteropod distribution and the aragonite compensation depth; Deep-Sea Res 25 447-452.

Berger A 1978 Long-term variations of daily insolation and Quaternary climate changes; J. Atmos. Sci. $352362-$ 2367.

Brock J C, McLain C R, Anderson D M, Prell W L and Hay W W 1992 Southwest monsoon circulation and environments of Recent planktonic foraminifera in the northwestern Arabian Sea; Paleoceanography 7 799-813.

Clemens S C and Prell W L 1990 Late Pleistocene variability of Arabian Sea summer monsoon winds and continental aridity: Eolian records from the lithogenic components of deep sea sediments; Paleoceanography 5 109-145.

Clemens S C, Prell W L, Murray D, Shimmied G and Weedon G 1991 Forcing mechanisms of the Indian Ocean monsoon; Nature 353 720-725.

Conan S M H and Brummer G J A 2000 Fluxes of planktonic foraminifera in response to monsoonal upwelling of the Somalia Basin margin; Deep-Sea Res. III 47 22072227 .

Cullen J L and Prell W L 1984 Planktonic foraminifera of the Northern Indian Ocean: Distribution and preservation in surface sediments; Mar. Micropal. 9 1-52.

Curry W B, Ostermann D R, Guptha M V S and Ittekot V 1992 Foraminiferal production and monsoonal upwelling in the Arabian Sea: Evidence from sediment traps; In: Upwelling Systems: Evolution since the Early Miocene, (eds) Summerhays C P, Prell W L and Emeis K C, Geol. Soc. Spec. Publ. 64 93-106.

Das S S, Maurya A S, Pandey A C, Bhan U and Rai A K 2008 Influence of sediment source and monsoonal variations on the late Quaternary clay mineral assemblages at ODP Site 728A, northwestern Arabian Sea; Curr. Sci. 95(9) 1320-1326.

den Dulk M, Reichart G J, Memon G M, Roelofs E M P, Zachariasse W J and van der Zwaan G J 1998 Benthic foraminiferal response to variations in surface water productivity and oxygenation in the northern Arabian Sea; Mar. Micropal. 35 43-66.

Emeis K C, Anderson D M, Doose H, Kroon D and SchulzBull D 1995 Sea surface temperatures and history of monsoon upwelling in the northwest Arabian Sea during the last 500,000 years; Quat. Res. 43 355-361.

Findlater J 1974 The low-level cross equatorial air current of the western Indian Ocean during the northern summer; Weather 29 411-416.

Gupta A K, Anderson D M and Overpeck J T 2003 Abrupt changes in the Asian southwest monsoon during the Holocene and their links to the North Atlantic Ocean; Nature 421 354-357, Pub Med, doi: 10.1038 /nature01340.

Gupta A K, Das M and Anderson D M 2005 Solar influence on the Indian summer monsoon during the Holocene; Geophys. Res. Lett. 32 L17703, doi: 10.1029/2005GL022685.

Gupta A K, Das M, Clemens S C and Mukherjee B 2008 Benthic foraminiferal faunal and isotopic changes as recorded in Holocene sediments of the northwest Indian Ocean; Paleoceanography 23 PA2214 10 pp., doi: 10.1029/2007PA001546.

Gupta A K, Sarkar De S S, Clemens S C and Velu A 2010 Mid-Brunhes strengthening of the Indian Ocean Dipole caused increased equatorial East African and decreased Australasian rainfall; Geophys. Res. Lett. 37 L06706 6 pp., doi: 10.1029/2009GL042225.

Haake B, Ittekkot V, Rixen T, Ramaswamy V, Nair R R and Curry W B 1993 Seasonality and inter annual variability of particle fluxes to the Arabian Sea; Deep-Sea Res. 40 1323-1344.

Hastenrath S 1989 The monsoonal regimes of upperhydrospheric strcture in the tropical Indian Ocean; Atmosphere-Ocean 27 478-507.

Hemleben C, Spindler M and Anderson O R 1989 Modern Planktic Foraminifera (New York: Springer-Verlag) $363 \mathrm{p}$.

Hilbrecht H 1997 Morphologic gradation and ecology in Neogloboquadrina pachyderma and $N$. dutertrei (planktic foraminifera) from core top sediments; Mar. Micropal. 31 $31-43$.

Ishikawa S and Oda M 2007 Reconstruction of Indian monsoon variability over the past 230,000 years: Planktic 
foraminiferal evidence from the NW Arabian Sea open ocean upwelling area; Mar. Micropal. 63 143-154.

Ivanova E, Schiebel R, Singh A D, Schmiedl G, Niebler H S and Hemleben C 2003 Primary production in the Arabian Sea during the last 135,000 years; Palaeogeog. Palaeoclim. Palaeoeco. 197 61-82.

Krey J and Bauered B 1976 Phytoplankton production; Atlas of the International Indian Ocean Expedition. Institüt fur Meereskunde an der Universität Kiel, 70 p.

Kuroyanagi A and Kawahata H 2004 Vertical distribution of living planktonic foraminifera in the seas around Japan; Mar. Micropal. 53 173-196.

Lee C M, Jones B H, Brink K H and Fischer A S 2000 The upper ocean response to monsoonal forcing in the Arabian Sea: Seasonal and spatial variability; Deep-Sea Res. II 47 1177-1226.

Madhupratap M, Kumar S P, Bhattathiri P M A, Kumar M D, Raghukumar S, Nair K K C and Ramaiah N 1996 Mechanism of the biological response to winter cooling in the northeastern Arabian Sea; Nature 384 549552.

Morse J W and Meckenzie F T 1990 Geochemistry of sedimentary carbonates; In: Developments in Sedimentology (New York: Elsevier) 48 707p.

Murray D W and Prell W L 1992 Late Pliocene and Pleistocene oscillations and monsoon upwelling recorded in sediments from the Owen Ridge, north-western Arabian Sea; In: Upwelling Systems: Evolution since the early Miocene (eds) Summerhayes CP, Prell WL and Emeis KC, Geol. Soc. Spec. Publ. 64 301-321.

Naidu P D and Malmgren B A 1995 A 2200 years periodicity in the Asian monsoon system; Geophys. Res. Lett. 22 2361-2364.

Naidu P D and Malmgren B A 1996 A high-resolution record of late Quaternary upwelling along the Oman Margin, Arabian Sea based on planktonic foraminifera; Paleoceanography 11 129-140.

Naidu P D and Malmgren B A 2005 Seasonal sea surface temperature contrast between the Holocene and last glacial period in the western Arabian Sea (Ocean Drilling Project site 723A): Modulated by monsoon upwelling; Paleoceanography 20 P1004, doi: 10.1029/2004PA001078.

Nair R R, Ittekkot V, Manganini S J, Ramaswamy V, Haake B, Degens E T, Desai B N and Honjo S 1989 Increased particle flux to the deep ocean related to monsoons; Nature 338 749-751.

Overpeck J T, Anderson D M, Trumbore S and Prell W L 1996 The southwest Indian monsoonv over the last 18,000 years; Clim. Dyn. 12 213-225, doi: 10.1007/ BF00211619.

Pattan J N, Toshiyuki M, Naidu P D, Parthiban G and Yamamoto M 2003 Productivity fluctuations in the southeastern Arabian Sea during the last 140 ka; Palaeogeog. Palaeoclim. Palaeoeco. 193 575-590.

Prell W L 1984 Variation of monsoonal upwelling: A response to changing solar radiation; In: Climate Processes and Climate Sensitivity (eds) Hansen J E and Takahashi T, Geophys. Monogr. AGU, 48-57.

Qasim S Z 1982 Oceanography of the northern Arabian Sea; Deep-Sea Res. 29(9A) 1041-1068.

Rai A K, Singh V B, Maurya A S and Shukla S 2008 Ventilation of northwestern Arabian Sea Oxygen Minimum
Zone: Pteropod record at ODP Site $728 \mathrm{~A}$ during past 175 kyrs; Curr. Sci. 94 480-485.

Reichart G J, den Dulk M, Visser H J, van der Weijden C H and Zachariasse W J 1997 A 225 kyr record of dust supply and the oxygen minimum zone from the Murray Ridge (northern Arabian Sea); Palaeog. Palaeoclim. Palaeoeco. 134 149-169.

Reichart G J, Lourens L J and Zachariasse W J 1998 Temporal variability in the north Arabian Sea Oxygen Minimum Zone (OMZ) during the 225,000 years; Paleoceanography 13 607-621.

Rogalla U and Andruleit H 2005 Precessional forcing of coccolithophore assemblages in the northern Arabian Sea: Implications for monsoonal dynamics during the last 200,000 years; Mar. Geol. 217 31-48.

Rostek F, Bard E, Beaufort L, Sonzogni C and Ganssen G 1997 Sea surface temperature and productivity records for the past $240 \mathrm{kka}$ in the Arabian Sea; Deep-Sea Res. II 44 1461-1480.

Schiebel R, Waniek J, Bork M and Hemleben C 2001 Planktic foraminiferal production stimulated by chlorophyll redistribution and entrainment of nutrients; Deep-Sea Res. I 48 721-740.

Schiebel R, Zeltner A, Treppke U F, Waniek J J, Bollmann J, Rixen T and Hemleben C 2004 Distribution of diatoms, coccolithophores and planktic foraminifers along a trophic gradient during southwest monsoon in the Arabian Sea; Mar. Micropal. 51 345-371.

Schmiedl G and Leuschner D C 2005 Oxygenation changes in the deep western Arabian Sea during the last 190,000 years: Productivity versus deepwater circulation; Paleoceanography 20 PA2008 14 pp., doi: 10.1029/ 2004PA001044.

Schmiedl G and Mackensen A 2006 Multispecies stable isotopes of benthic foraminifers reveal past changes of organic matter decomposition and deepwater oxygenation in the Arabian Sea; Paleoceanography 21 PA4213 14 pp., doi: 10.1029/2006PA001284.

Schulz H, von Rad U and Erlenkeuser H 1998 Correlation between Arabian Sea and Greenland climate oscillations of the past 110,000 years; Nature 393 54-57.

Sirocko F, Sarnthein M, Lange H and Erlenkeuser H 1991 Atmospheric summer circulation and coastal upwelling in the Arabian Sea during the Holocene and the last glaciations; Quat. Res. 36 72-93.

Steens T N F, Kroon D, Ten Kate W G and Sprenger A 1991 Late quaternary periodicities of oxygen isotope ratios, calcium carbonate contents, and magnetic susceptibilities of western Arabian Sea Margin Hole 728A; In: Proceedings ODP (eds) Prell WL et al Scientific Results $\mathbf{1 1 7}$ 309-320.

Veldhuis M J W, Kraay G W, van Bleijswijk J D L and Baars M A 1997 Seasonal and spatial variability in phytoplankton biomass, productivity and growth in the Indian Ocean: The southwest and northeast monsoon, 19921993; Deep-Sea Res. I 44 425-449.

Wyrtki K 1971 Oceanographic Atlas of the International Indian Ocean Expedition; National Science Foundation, Washington D.C., 531p.

Wyrtki K 1973 Physical oceanography of the Indian Ocean; In: The Biology of the Indian Ocean (ed.) Zeitschel B (Berlin: Springer), 18-36. 